\title{
MENINGKATKAN HASIL BELAJAR SISWA DENGAN MEMPERGUNAKAN METODE PROBLEM SOLVING PADA KELAS III SD NEGERI 12 CIMPARUH KOTA PARIAMAN
}

\author{
ELLY MARIUS \\ SD Negeri 12 Cimparuh Kota Pariaman
}

\begin{abstract}
This type of research is Classroom Action Research (CAR). Therefore, in accordance with classroom action research, the research problem that must be solved comes from the problem of learning practices in the classroom more professionally. The results of observations of observations in the first cycle of the implementation of problem solving methods experienced positive developments. namely in the first cycle the average activity of students $43 \%$ to $82 \%$ or an increase of $395 \%$, while the learning outcomes of students in the first cycle averaged 65.36 with a mastery level reaching 46\%. In the second cycle the average student learning outcomes were 85 and student completeness was 93\%. From the results of the research carried out for 2 cycles by using the problem solving method, there was a good rise, so the implementation of the problem solving method was suitable for use in Thematic learning sub theme I.
\end{abstract}

Keywords: Student Learning, Problem Solving Method, SD Negeri 12 Cimparuh.

\begin{abstract}
Abstrak: Jenis penelitian ini adalah Penelitian Tindakan Kelas (PTK). Oleh karena itu, sesuai dengan penelitian tindakan kelas, masalah penelitian yang harus diselesaikan berasal dari masalah praktik pembelajaran di kelas secara lebih profesional. Hasil observasi observasi pada siklus I penerapan metode pemecahan masalah mengalami perkembangan positif. yaitu pada siklus I rata-rata aktivitas siswa $43 \%$ menjadi $82 \%$ atau meningkat $395 \%$, sedangkan hasil belajar siswa pada siklus I rata-rata 65,36 dengan tingkat ketuntasan mencapai 46\%. Pada siklus II rata-rata hasil belajar siswa 85 dan ketuntasan siswa 93\%. Dari hasil penelitian yang dilaksanakan selama 2 siklus dengan menggunakan metode pemecahan masalah terdapat peningkatan yang baik, sehingga penerapan metode pemecahan masalah sesuai untuk digunakan dalam pembelajaran Tematik sub tema I.
\end{abstract}

Kata Kunci: Belajar Siswa, Metode Problem Solving, SD Negeri 12 Cimparuh.

\section{A. Pendahuluan}

Pembelajaran tematik adalah pembelajaran yang memadukan antara berbagai mata pelajaran atau bidang studi dengan menggunakan tema tertentu. Tema tersebut kemudian diulas atau dilaborasi dari berbagai sudut pandang baik dari pandangan ilmu pengetahuan,humaniora maupun agama, sehingga memberikan pengalaman bermakna bagi anak didik. Pembelajaran tematik anak didik diharapkan mendapatkan hasil belajar yang optimal dan maksimal dan meghindari kegagalan pembelajaran yang masih banyak terjadi dengan model dan metode pembelajaran yang lain. Kegiatan pembelajaran tersebut mencangkup pengembangan kemampuan dalam mengajukan pertanyaan, mencari jawaban, memahami jawaban, menyempurnakan jawaban tentang "'apa", "mengapa" dan "bagaimana" tentang tema tersebut.

Metode yang berbeda mampu mengembangkan daya berfikir siswa. Terjadinya ledakan pengetahuan, menurutnya menuntut perubahan pola mengajar dari yang sekedar mengingat fakta yang biasa dilakukan melalui proses teacher center dan 
berobah dengan melaksanakan metode pembelajaran yang beraneka ragam. Dengan beragamnya metode dan model mampu mengembangkan kemampuan berfikir kritis siswa. Pada pembelajaran tema 1 selama ini siswa kurang tertarik untuk membahas materi tersebut, dan hanya sebagian kecil yang mau untuk mempelajarinya. Hal ini disebabkan oleh proses pembelajaran yang monoton, sehingga siswa tidak ada keinginan untuk mempelajarinya. Kalau siswa kurang tertarik maka hasil belajar siswa juga rendah. Untuk meningkatkan aktivitas dan hasil belajar siswa maka pergunakan metode yang beragam dan sesuai dengan materi yang dibahas.

Untuk kepentingan ini, maka guru dituntut untuk mempunyai pengetahuan dan keterampilan menggunakan berbagai model dan metode dalam mengajar. Ada beberapa metode yang dapat digunakan dalam proses pembelajaran yaitu daam pendekatan proses: metode problem Solving, metode demonstrasi dan juga inkuiri. Metode Problem Solving adalah metode yang menuntut siswa untuk bisa berperan aktif dalam memecahkan suatu masalah dan bisa menemukan hal-hal baru yang berkaitan dengan pembelajaran. Metode pembelajaran Problem Solving dapat dibincangkan dari berbagai persfektif pedagogi, Problem Solving mencerminkan metode pembelajaran kontektual atau seiring dirujuk sebagai pembelajaran aktif.

Seiring dengan hal tersebut, peneliti mencoba memberikan solusi yang menurut peneliti mampu memperbaiki keadaan yang terlihat tersebut. Peneliti yakin bila beberapa hal yang peneliti tawarkan dalam PTK ini apabila dapat diterapkan dengan sebaik-baiknya dalam pembelajaran Tema 1 khususnya materi sub tema 1 yaitu ciri ciri makhluk hidup. Peneliti meaksanakan penelitian ini dengan judul " Meningkatkan Hasil Belajas Siswa dengan mempergunakan metode Problem Solving pada Kelas III SD Negeri 12 Cimparuh Kota Pariaman"

Berdasarkan latar belakang dan permasalahan yang telah dipaparkan pada bahagian terdahulu masalah umum Bagaimanakah Meningkatkan Hasil Belajar Siswa Melalui metode Problem Solving dalam Pembelajaran Tema 1 dikelas III SD Negeri 12 Cimparuh Kota Pariaman? Tujuan tindakkan kelas ini adalah untuk mengetahui peningkatan hasil belajar siswa melalui metode Problem Solving dalam pembelajaran Tema 1 di kelas III SD Negeri 12 Cimparuh Kota Pariaman.

\section{B. Metodologi Penelitian}

Penelitian ini dilaksanakan di SD Negeri Lapai Kota KecamatanPariaman Selatan Pariaman. Dilaksanakan pada kelas III SD Negeri 12 Cimparuh. Pelaksanaan penelitian dilakukan pada semester 1 TP 2019/2020 yaitu mulai bulan Agustus Oktober 2019. Jenis penelitian yang dilaksanakan adalah Penelitian Tindakan Kelas (PTK). Oleh sebab itu sesuai dengan penelitian tindakan kelas maka masalah penelitian yang harus dipecahkan berasal dari persoalan dalam proses pembelajaran dikelas sacara lebih profesional. Sesuai dengan rumusan masalah hasil studi pendahuluan peneliti bersama guru membuat rencana tindakan yang akan dilakukan. Tindakan itu berupa pembelajaran Tematik sub tema 1 dengan menggunakan metode problem solving. Kegiatan ini dimulai dengan merumuskan rancangan tindakan pembelajaran Tematik berdasarkan Metode problem solving. Data penelitian berupa hasil pengamatan, wawancara, catatan lapangan dan dokumentasi dari setiap tindakan perbaikan pembelajaran tematik dengan menggunakan Metode Problem Solving pada siswa kelas III SD yang diteliti. Data tersebut tentang hal-hal yang berkaitan dengan perencanaan, pelaksanaan dan hasil pembelajaran yang berupa informasi. Sumber data penelitian adalah proses belajar mengajar Tematik pada sub tema 1 yaitu Perkembangan dan pertumbuhan makhuk hidup dengan menggunakan Metode \begin{tabular}{lll}
\hline EISSN 2657-0289 & Lembaga Penelitian dan Penerbitan Hasil Penelitian Ensiklopedia & 37
\end{tabular} 
Problem Solving yang meliputi: perencanaan pembelajaran pelaksanaan pembelajaran yang terdiri dari tahap merumuskan masalah, tahap saat mengamati atau melakukan observasi tahap menganalisis atau menyajikan dan mengkomunikasikan hasil penyajian pada teman-teman yang lain kegiatan evaluasi perilaku guru dan siswa sewaktu PBM.

\section{Hasil dan Pembahasan}

Pembelajaran siklus 1 diamati oleh guru kelas III SD Negeri 12 Cimparuh Kota Pariaman sekaligus peneliti, bahwa dalam pembelajaran siklus 1 peneliti telah melaksanakan dengan hasilnya aktivitas dan hasil belajar siswa sebagai berikut: Hasil pengamatan adalah bahwa hasil belajar siswa dengan mmpergunan metode problem Solving pada materi sub tema I masih rendah dengan tingkat rerata mencapai 65,36 , ini masih dibawah KKM. Tingkat ketuntasannya adalah 52\% (11) orang yang telah mencapai nilai diatas KKM. Pembelajaran siklus I difokuskan pada ciri - ciri makhluk hidup melalui metode problem solving, pembelajaran dilaksanakan dengan menerapkan diskusi kelompok untuk memperoleh data tentang pelaksanaan siklus I dilakukan pengamatan, tes, dan catatan lapangan. Hasil pengamatan, tes, dan catatan lapangan selama pelaksanaan tindakan dianalisis.

Dari penelitian pada siklus I maka untuk melanjutkan ke siklus II guru akan menerapkan kembali pelaksanaan siklus II dengan cara yang lebih baik, dimana hasil tes siklus I menunjukkan bahwa jawaban belum sesuai dengan apa yang telah diharapkan. masih ada sebagian siswa yang masih mengalami kesulitan dalam menjawab soal yang dikerjakan. Pada siklus II materi penelitian dengan tema 1 dan sub tema 1 ciri - ciri makhluk hidup dengan Indikator: membilang secara urut bilangan 1.000 sampai dengan 10.000 (CI) melalui metode Problem Solving. Siklus II ini dilaksanakan atau dilakukan 1 kali pertemuan yang diadakan pada tanggal 4 September 2018 dengan jumlah siswa 21 orang.

Hasil refleksi pada siklus I menunjukan subjek penelitian belum mencapai tujuan pembelajaran yang diharapkan. Karena itu pembelajaran dilanjutkan dengan siklus II. Pembelajaran siklus II diberikan agar siswa dapat menentukan langkah-langkah metode Problem Solving melalui diskusi kelompok. Pembelajaran siklus II dilaksanakan dalam 1 kali pertemuan dengan alokasi waktu 4 × 35 menit.

Tujuan umum pembelajaran adalah siswa mampu Mengidentifikasi perbedaan pertumbuhan dan perkembangan. Menjelaskan perbedaan pertumbuhan dan perkembangan, Menuliskan perbedaan pertumbuhan dan perkembangan dirinya. Menentukan hasil penjumlahan, Menyelesaikan masalah sehari-hari terkait penjumlahan: langkah - langkah kegiatan adalah (a)Perumusan masalah yang akan dipecahkan oleh siswa, (b)menetapkan jawaban sementara atau hipotesis, (c) Siswa mencari informasi, (d)menarik kesimpulan atau generalisasi, dan (e) mengaplikasikan kesimpulan atau generalisasi dalam situasi baru.

Sebagaimana halnya siklus I dan siklus II, Pembelajaran siklus II diamati peneliti sekaligus guru kelas III SD Negeri 12 Cimparuh Kota Pariaman dan sekaligus melaporkan bahwa peneliti dalam pembelajaran siklus II telah melaksanakan tugas dengan baik. Dari hasil pengamatan siklus II diperoleh data aktivitas siswa dan nilai ketuntasan siswa siklus II. Hasil aktivitas siswa meningkat dibandingkan dengan siklus I, rerata aktivitas siswa pada siklus I adalah 43\%, sedangkan siklus II mencapai 90\%, naik sekitar $47 \%$. Hasil belajar siswa berkaitan dengan aktivitas siswa. Kalau aktivitas baik maka hasil belajar akan baik. Hasil belajar siswa pada siklus I rerata mencapai 
65,36 dengan siswa yang tuntas 11 orang (52\%), yang tidak tuntas 10 orang (48\%). Pada siklus II rerata hasil belajar siswa menjadi 87,5 naik sekitar 22,14 poin. Dan yang tuntas mencapai 20 orang (96\%). Untuk ketuntasan belajar siswa naik sekitar $46 \%$.

Dari analisis penelitian siklus I nilai rata-rata kelas baru 65,36. Berdasarkan nilai rata-rata 87,5 ,. berdasarkan hasil pengamatan siklus II yang diperoleh maka pelaksanaan siklus II sudah baik dan guru sudah berhasil dalam usaha peningkatan hasil belajar Sub Tema 1 yang digunakan dengan menggunakan Metode Ptoblem Solving pada kelas III Sekolah Dasar Negeri 12 Cimparuh Kota Pariaman. Menurut Rochman Natawijaya (!992: 73) "Belajar ialah proses pembinaan yang terus menerus yang terjadi dalam diri individu yang tidak ditentukan oleh unsur keturunan, tetapi lebih banyak ditentukan oleh faktor-faktor dari luar anak. Dalam belajar anak lebih banyak memperoleh pengetahuan dari guru, maka guru harus lebih memahami kembali tiga aspek dalam pendidikan, proses belajar yang belajar adalah anak didik atau siswa yang secara individu atau kelompok mengikuti suatu proses belajar dalam suasana tertentu.

Guru sebagai penggerak dan pengatur proses belajar mengajar sudah seharusnya dapat mengaktifkan semua siswa tanpa kecuali agar potensi yang ada pada diri siswa dapat tergali dan berkembang. Guru dapat memberikan motivasi pada siswa dalam pembelajaran sebagaimana diungkapkan Rochman Natawijaya (1992:70). Peranan guru dalam memberi motivasi anak adalah "mengenal sikap siswa yang diajarkan secara pribadi, memperhatikan interaksi yang menyenangkan, menguasai berbagai metode dan teknik mengajar serta menggunakannya dengan tepat, menjaga suasana kelas jangan terjadi konflik ,menghargai siswa sesuai dengan kemampuannya.

Dengan menggunakan Metode Problem Solving dalam pembelajaran Sub Tema 1 dapat meningkatkan hasil belajar siswa Menurut Moejdiono (1993:83) Metode Problem Solving digunakan dalam pembelajaran bertujuan untuk: Meningkatkan keterlibatan siswa secara aktif dalam memperoleh dan memproses perolehan belajar,(b)Mengarahkan siswa sebagai pelajar seumur hidup,(c) Mengurangi ketergantungan kepada guru sebagai satu-satunya sumber informasi yang diperlukan oleh siswa,(d)Melatih siswa mengeksplorasi atau memanfaatkan lingkungan sebagai sumber informasi yang tidak akan pernah tuntas untuk digali

\section{Penutup}

Bedasarkan temuan hasil penelitian dalam meningkatkan hasil belajar dengan menggunakan Metode Problem Solving pada pembelajaran Sub Tema I, maka kesimpulannya dapat dikemukakan adalah: Metode Problem Solving dapat meningkatkan hasil belajar siswa. Metode Problem Solving dapat meningkatkan keterlibatan siswa secara aktif dalam memperoleh dan memproses perolehan belajar. Penggunakaan Metode Problem Solving dapat memotifasi siswa untuk menemukan sesuatu yang baru. Dengan menggunakan Metode Problem Solving guru sudah tidak merupakan faktor dominan lagi dalam proses belajar melainkan berfungsi sebagai fasilitator dan dinamisator kelas. Penggunaan Metode Problem Solving dapat meningkatkan hasil belajar Sub Tema I

\section{Daftar Pustaka}

Gulo,W.2002. Strategi Belajar Mengajar. Jakarta : PT. Gramedia Widiasarana Indonesia

Hamalik. 2004. Pendekatan Baru Strategi Belajar Mengajar Berdasarkan CBSA. Bandung. CV. Sinar Baru Algensindo 
Kemmis,Stephen dan Robin Mc Taggart. 1988. The Action Research Planner. Victoria:Deakin University

Maslichah. 2006. Penerapan Pendekatan Sains Teknologi Masyarakat. Yokyakarta: Universitas Sanata Dharma

Moejdiono dan Dimyati.1993. Strategi Belajar Mengajar. Jakarta : Depdikbud, Dirjen Dikti, P2LPTK

Moejdiono dan Dimyati. 2006. Belajar dan Pembelajaran. Jakarta : Rineka Cipta

Munandir, 1999. Evaluasi dan Penelitian tindakkan, Malang:FIP-IKIP Malang

Nasution. 2003. Strategi Belajar Mengajar.Jakarta:Reneka Cipta

Purwanto. 1996. Psikologi Pendidikan. Bandung: Remaja Rosdakarya.

Ritawati Mahyuddin dan Yetti Ariani.2007. Hand Out Metodologi Penelitian Tindakan kelas. Padang : FIP UNP

Sanjaya, Wina.2008. Strategi Pembelajaran Berorintasi Standar Proses Pendidikan. Jakarta : Kencana

Sudjana, Nana.1995. Dasar-dasar Pembelajaran. Bandung : Sinar Baru Algensindo

Suharsimi Arikunto. 1999. Dasar-dasar Evaluasi Pendidikan. Jakarta: Bumi aksar 